\title{
A VIOLÊNCIA VISTA DE PERTO: OS LIMITES DA DOCUMENTAÇÃO DA DOR, DA DENÚNCIA E DA DEMANDA POR JUSTIÇA
}

Fabiene Gama ${ }^{1}$

UnB, Brasília, Brasil

\begin{abstract}
Este artigo trata da documentação fotográfica do cadáver de uma criança assassinada por policiais em uma favela do Rio de Janeiro, e dos acontecimentos que sucederam sua divulgação. Produzido por um jovem fotógrafo morador da mesma favela, Naldinho Lourenço, a documentação e as reaçóes a ela apontam para as dinâmicas e os limites do registro fotográfico da violência policial por fotógrafos populares. O fotógrafo é parte do Imagens do Povo, uma agência de fotógrafos que visa produzir imagens positivas das populaçôes pobres, a fim de combater estereótipos enfrentados por tal população, relacionados ao tráfico de drogas. Configurando uma exceção à produção do grupo, tal documentação gerou ameaças ao fotógrafo e fez com que o grupo ponderasse sobre as possibilidades, as necessidades e as consequências da realização desse tipo de registro. Através de discursos, imagens e eventos, reflito sobre a autorrepresentação fotográfica de moradores de favelas no Rio.
\end{abstract}

Palavras-chave: fotografia, violência policial, ativismo, favelas, Rio de Janeiro

Todo o indivíduo tem direito à liberdade de opinião e de expressão, o que implica o direito de não ser inquietado pelas suas opinióes e o de procurar, receber e difundir, sem consideração de

\footnotetext{
1 Contato: fabienegama@gmail.com. Este artigo foi escrito graças a bolsas de estudos recebidas da CAPES durante meu doutorado no PPGSA/UFRJ e pós-doutorado no DAN/UNB. Ele é fruto da interlocução estabelecida com os fotógrafos e coordenadores do Imagens do Povo, especialmente Naldinho Lourenço, que teve enorme paciência e generosidade ao compartilhar comigo suas histórias, experiências e sentimentos. A ele sou profundamente grata. Agradeço ao Prof. Marco Antonio Gonçalves por ter lido uma versão preliminar deste texto.
} 
fronteiras, informaçôes e ideias por qualquer meio de expressão. Art. 19, Declaração Universal dos Direitos Humanos

O artigo 19 da Declaração Universal dos Direitos Humanos, que defende a liberdade de expressão, é um lema para o Imagens do Povo, ${ }^{2}$ um programa de documentação e formação de fotógrafos que conta com uma Agência, uma Escola de Fotógrafos Populares e um Banco de Imagens. Situado no Conjunto de Favelas da Maré, no Rio de Janeiro, o programa fundado em 2004 pelo fotógrafo documentarista João Roberto Ripper oferece cursos gratuitos e assistência profissional a moradores de favelas cariocas com o objetivo de produzir imagens positivas dessas áreas e de seus habitantes. Desejam combater estereótipos negativos sobre essa população, que relacionam a criminalidade à pobreza e provocam uma série de intervenções do Estado, através da polícia, gerando violências simbólicas e físicas, muitas vezes letais. De acordo com o site do grupo,

O foco crítico consiste em formar e promover documentaristas fotográficos, potenciais multiplicadores do saber adquirido, capazes de desenvolver trabalhos autorais de registro de espaços populares, valorizando as histórias e as práticas culturais de suas comunidades, além de estimular o fortalecimento de vínculos identitários a partir do uso da linguagem fotográfica, que se torna instrumento de acesso e mapeamento de diferentes expressões culturais e sociais dos territórios onde residem, ampliando as possibilidades de difusão de novas imagens destes locais. ${ }^{3}$

Entre 2008 e 2012, período deste pesquisa, o Artigo 19 aparecia reproduzido em seus vídeos, exposições e publicações do grupo. ${ }^{4}$ Utilizavam-no para chamar a atenção para o direito de produzir suas histórias sobre as favelas, investindo em imagens de "amor", "alegria", "solidariedade" e "sensualidade" de seus moradores, opondo-se à extensiva representação dessas pessoas como criminosas, atuantes no mercado varejista de drogas. Ou seja, a maioria dos fotógrafos não se interessava em documentar conflitos armados ou a violência policial: eram temas já bastante documentados pela grande mídia. Registravam, no máximo, protestos de familiares que perdiam seus filhos por causa desses conflitos, em especial da violência praticada pelos agentes do Estado nessas áreas. ${ }^{5}$

Uma exceção que acabou por demarcar os limites da atuação do grupo foi a documentação que Naldinho Lourenço fez do cadáver de Matheus Rodrigues, uma criança de oito anos assassinada pela policia, em 2008. Após a divulgação das imagens em diferentes mídias, uma série de acontecimentos ocorreram, exigindo que o grupo refletisse sobre as possibilidades, as necessidades e as consequência de tal documentação fotográfica. Acompanhei este momento crítico de perto e pude, através da combinação de discursos, imagens e eventos refletir sobre os limites da autorrepresentação fotográfica de moradores de favelas no Rio de Janeiro. É sobre tais reflexões que trata este artigo.

O formato no qual aqui apresento minhas análises é fruto de discussões teóricas sobre movimentos sociais (Farias, 2014; Jasper 1998), autorrepresentações fotográficas em favelas (Gama

2 Ainda que se trate de uma agência, substantivo feminino, os fotógrafos do grupo se referem ao Imagens do Povo no masculino. A utilização do artigo masculino parece indicar que as pessoas vinculadas à agência a veem como um projeto social, mas não refletirei aqui sobre esta utilização. Em respeito ao seu uso corrente, também reproduzirei aqui este uso equivocado.

$3 \mathrm{http} / /$ www.imagensdopovo.org.br/apresentacao/

4 Ver, por exemplo, o link http://www.youtube.com/watch?v=Rc7LLI0QDBM

5 Para saber mais sobre a violência policial praticada em favelas cariocas, ver Juliana Farias (2014) e Adriana Vianna e Juliana Farias (2011) e Patrícia Lanes (2015). 
2006; 2009 e 2012; Carminati 2008; Valdean 2013) e emoções em mobilizações políticas (AbuLughod e Lutz 1990); assim como de metodologias que permitiram unir minhas narrativas textuais às discursivas e visuais de Naldinho. Investindo em um estilo literário inspirado por estas referências, limitei a utilização de citações bibliográficas ao imprescindível, optando por apresentar minhas reflexões de forma mais fluida. As emoções, tal como são apresentadas aqui, servem para dar o tom dos acontecimentos e explicitar as tensões experimentadas, imprescindíveis para a compreensão dos interditos na documentação sobre a qual reflito.

\section{Contextualizando a violência}

Para entendermos os limites do ativismo político de fotógrafos moradores de favelas cariocas é preciso atentarmos para como a violência é praticada e concebida no Brasil. Pois além da violência física explícita praticada pela polícia contra jovens negros nas favelas e fora delas, há censuras impostas através de ameaças e da imposição do medo. Obstáculos que não apenas dificultam a realização e a divulgação de imagens sobre violências, como colocam em risco a vida de quem as fotografa. ${ }^{6}$ A documentação da violência - política - vivida por Matheus serve para refletirmos sobre onde são impostos os limites imagéticos, performáticos e discursivos dos trabalhos realizados por fotógrafos subalternos. E oferece pistas sobre como o Estado atua nessas áreas.

O que é considerado uma "violência política" teoricamente é motivo de controvérsias, como demostraram Teresa Caldeira (1993) e Glaucio Soares (1993). A maioria das definições, contudo, apresentam-na como a violência ilegal praticada pelos aparelhos do Estado, indivíduos ou grupos sociais em nome de demandas políticas. Assassinatos, prisões ilegais, execuções sumárias, genocídios, guerras, terrorismo, tortura e violência policial são algumas formas da violência compreendida como política - todas praticadas pelo Estado em favelas cariocas.

Para Caldeira (1993: 47), as noções do que é violento, aceitável ou criminoso são construídas socialmente. E o que se considera passível ou não de divulgação a respeito são decisões políticas. Mas a autora chama a atenção para o fato de que

A prática da cidadania no Brasil tem como desafios centrais a violência policial e a prática da justiça. Os dados "nacionais" subestimam em uns contextos ou superestimam em outros os números da violência, ou seja, constroem politicamente os indicadores e as noções de violência política, tanto quanto os dados "globais". A crítica às construções nacionais é assim tão importante quanto aquela das fontes internacionais, e é ela que pode nos indicar que o ocultamento da violência policial como não-política e no limite como não-violência é um dado fundamental do padrão nacional de dominação política. Afinal, o Brasil contemporâneo, sem violência política em sentido estrito, parece estar longe de ser um país menos violento e com aparelhos repressivos menos violentos do que o foi durante o regime militar, como parece estar longe de ser um país em que o exercício da cidadania, embora estendido politicamente, tenha sido ampliado de maneira considerável no que se refere aos direitos individuais. (Caldeira 1993: 47).

Ainda para a autora, a separação entre violência política e policial é difícil, visto que ambas são praticadas ou aceitas pela mesma instituição, o Estado. Desse modo, compreender a violência cotidiana praticada contra a população pobre e negra é aprender um aspecto fundamental da

$6 \quad$ Este movimento de fotógrafos populares surgiu no Brasil em 2004 e teve seu ápice em 2008, antes do Facebook e das mídias alternativas se popularizarem como meio de denúncia da violência policial. Algo que aconteceu durante as manifestações de 2013. 
violência na sociedade brasileira. Para entendermos sua complexidade e como ela funciona na prática, apresentarei Naldinho, algumas de suas fotos, seus discursos e repercussões do seu trabalho. Meu objetivo, com isto, é analisar as dinâmicas da prática de fotógrafos populares, assim como das diversas violências que experimentam no seu dia-a-dia.

A história do fotógrafo foi construída através da etnobiografia: ao relatar suas experiências individuais na interação comigo, Naldinho e eu criamos uma narrativa que aborda tanto a etnografia quanto a biografia, ultrapassando as fronteiras que tendem a situar subjetividade e objetividade ou cultura e personalidade em campos opostos. A força dessa narrativa está em abordar indivíduos com nomes, opiniões e problemas com os quais nos identificamos, e não generalizações abstratas como "os favelados” ou "a sociedade”. (Prelorán 1987).

\section{UM FOTÓGRAFO POPULAR}

Nascido em 1983, Naldinho viveu quase toda sua vida na Baixa do Sapateiro, uma das favelas da Maré. Filho caçula de migrantes nordestinos, só conhecia cinco dos seus dez irmãos em 2009. A maioria permaneceu no Rio Grande do Norte quando seus pais migraram para o Sudeste do Brasil. Foi apenas em 1999, quando seus pais voltaram a morar na cidade de sua avó, por causa de uma intensa guerra entre traficantes na Maré, que ele conheceu o Nordeste. Ficaram onze meses, durante os quais ele cursou o primeiro ano do Magistério. Nunca interrompeu seus estudos até se formar no Ensino Médio, sendo ele mesmo o responsável por suas inscrições. Não gostava que seus pais se envolvessem.

Assim, quando voltou para o Rio, tentou se inscrever na escola mais perto da sua casa, mas não conseguiu uma vaga. Inconformado com o fato de ter que suspender os estudos e se inscrever em uma escola distante, foi ao juizado de menores exigir uma vaga na escola perto de sua casa. Conseguiu uma carta do juiz garantindo sua inscrição e voltou à escola, dizendo: "agora tem vaga”. Obrigou, assim, a diretoria da escola a aceitá-lo, e recomeçou a estudar.

Foi o primeiro dos irmãos na cidade a terminar os estudos. Sua mãe nunca estudou e seu pai concluiu a 5a série do antigo primário. Além do ensino formal, Naldinho juntou dinheiro trabalhando na lanchonete de sua mãe na Maré para pagar um curso de informática e outro de línguas, mas acabou abandonando ambos. Os conhecimentos adquiridos, contudo, utilizou no trabalhou que passou a desenvolver, a partir de 2000, no Centro de Estudos e Ações Solidárias da Maré (CEASM). ${ }^{7}$

Ao concluir o Ensino Médio, em 2002, tentou por três vezes uma vaga em um curso superior, mas não teve sucesso. Desistiu. Em 2004 foi indicado pelo CEASM para a primeira turma da Escola de Fotógrafos Populares, passando a atuar como fotógrafo desde então. Sua vinculação à $\mathrm{ONG}$ lhe ofereceu algumas vantagens: acesso a equipamentos, redes de contatos e uma formação "na militância", que se transformou em fotoativismo no Imagens do Povo. Ativismo que consiste em utilizar as fotografias como ferramenta de atuação política. Naldinho costumava, por exemplo, distribuir suas fotos gratuitamente, prática que compartilhava com outros fotógrafos do grupo. Buscava impactar as representações das populações mais pobres do

7 ONG que oferecia cursos de fotografia, vídeo, produção gráfica, produção literária e produção artística. 
país fazendo suas imagens circularem amplamente, pouco se preocupando com os valores pagos por elas.

Não costumava escrever textos ou legendas para suas fotos, investindo em narrativas muitas vezes apresentadas coletivamente pelo grupo. Mas passou a repensar tal prática a partir da documentação do Matheus:

Eu não tinha essa prática [de escrever]. Na fotografia documental, o ideal é que você faça isso. Mas quando você bota a descrição básica, sobre o que é que é: carrinho de rolimã, Baixa do Sapateiro, crianças... Eu acho que isso já dá um incremento na imagem. Aí quando você bota: Juliano, 17 anos, morador da Baixa do Sapateiro, brinca próximo à sua casa, é outra coisa... Aí quando mostra que morreu uma criança perto ali da Baixa do Sapateiro, como vai ser esse discurso? Quando o Matheus morreu, as informações que apareceram eram de que ele era traficante. ${ }^{8}$

A escrita é um desafio para os fotógrafos populares. Mas a contextualização de um caso de violência - notadamente de um assassinato - experimentado em uma favela é importante porque seus moradores são comumente acusados de envolvimento com a criminalidade. Ainda que tenham pouca idade. Ou seja, na ausência de "provas" que demonstrem a idoneidade dos mortos, quando negros e favelados, ainda que crianças, seus assassinatos são aceitos como justificáveis perante a sociedade. ${ }^{9}$ Vejamos como aconteceu o caso de Matheus.

\section{A documentação do Cadáver de Matheus Rodrigues ${ }^{10}$}

Naldinho tinha 25 anos no dia 04 de dezembro de 2008 quando, saindo de casa rumo ao CEASM, ouviu sua mãe dizer: "mataram uma criança". Matheus tinha 8 anos e saía de casa para comprar pão quando foi atingido por um tiro de fuzil disparado por um policial na Baixa do Sapateiro. Ao tomar conhecimento da morte do menino, o fotógrafo enviou um e-mail avisando ativistas de direitos humanos do ocorrido e seguiu para a ONG. Chegando lá, soube detalhes do crime e decidiu ir até o local fotografar.

Aí quando teve a manifestação, todos foram e eu fiquei sozinho. O corpo tava lá. Aí eles [os moradores] decidiram fechar a Av. Brasil. Tinham alguns fotógrafos lá. [...] Eu fiquei. Estava o Alessandro Molon [presidente da Comissão de Direitos Humanos da Alerj]. E tinha a Marielle [Comissão de Direitos Humanos da Alerj] que estava dando uma ajuda. [A polícia] precisava fazer as fotos e a perícia não tinha fotógrafo no local. Aí a Marielle falou: ele pode fazer as fotos. E eu fui fazer as fotos para a perícia. Tira o tecido [que cobria o corpo do Matheus], faz as fotos, tal. "Fotografa isso aqui, mais próximo". Aí tem uma bala, tal. Quando a tia e o tio da criança e a presidente de uma ONG chamada Uerê tiraram [o tecido] e botaram a criança no chão, eu fiz uma foto dela sem o pano. Aí a perícia veio e cobriu o corpo. Quando cobriu, ficou só a mão da criança com a moeda [para fora]. Eu falei: isso aqui deve ser a foto! Aí fui e fiz umas três ou quatro imagens.

A perícia da polícia não contava com um fotógrafo no local, e coube a ele registrar imagens do cadáver de Matheus. Durante o registro, documentou detalhes do corpo baleado da criança de diferentes ângulos. Sendo a primeira vez que via um corpo baleado de tão perto, o evento marcou sua vida. Prevalecendo-se da proximidade com a cena do crime, contudo, aproveitou a

$8 \quad$ Todas as citações de Naldinho são de entrevista concedida à autora em 29 de junho de 2012.

9 José Mariano Beltrame, por exemplo, Secretário de Segurança Pública do Rio de Janeiro, disse em uma declaração em 2007: "Mesmo morrendo crianças, não há outra alternativa. Esse é o caminho". Para saber mais sobre este assunto, ver Juliana Farias (2014).

10 Por limitação do número de imagens publicáveis na revista, o ensaio completo não pôde ser publicado. 
oportunidade para fazer algumas fotos que pudessem ser utilizadas para seu ativismo. Após os registros, e ainda no calor da emoção, voltou para o CEASM e, a fim de prevenir que a polícia acusasse Matheus de envolvimento com o tráfico de drogas, enviou as imagens junto com um texto escrito por Gizele Martins e Silvana Sá, jornalistas da Rede Nacional de Jornalistas Populares e moradoras da Maré, para vários ativistas de direitos humanos e mídias alternativas.

Ao questioná-lo sobre o porquê de divulgar imagens de um cadáver, Naldinho respondeu que gostaria de denunciar o assassinato e garantir a idoneidade das informações que seriam veiculadas pela grande mídia:

A imagem de uma criança, né? Eu queria que fosse divulgada. Porque eu sabia que isso ia passar na mídia como a morte de um traficante. E foi realmente o que falaram. "Tem que analisar", o Wagner Montes falou... "Tem que analisar...". E depois se retratou: "Não, realmente foi uma criança....". Entendeu? [...] As imagens tiveram uma repercussão muito grande. Veio até jornalista do Washington Post pedir para eu relatar o que tinha acontecido. Veio gente do New York Times... E estava em outros jornais também. Saiu em um jornal chamado A Democracia, que circula no centro. Estava no Expresso no outro dia.

Este "evento crítico" (Das 1995) - o violento assassinato de uma criança - chocou a sociedade e gerou repercussões dentro e fora do Conjunto de Favelas da Maré, ultrapassando o grupo de interesse dos organismos que lidam com os direitos humanos no Rio de Janeiro. A pouca idade de Matheus somada às imagens produzidas por Naldinho foram fatores que ampliaram a comoção em torno do caso. Suas fotos serviram como prova da violência praticada pela polícia militar (PM) nas favelas, e como indício de que suas incursões nessas áreas causam perdas que não poderiam ser enquadradas nos já banais "autos de resistência"

Para o ensaio sobre o assassinato de Matheus, Naldinho documentou seu corpo, seu enterro e o protesto que se seguiu. As fotos mostram situações distintas: enquanto nas do crime ele foca no corpo da criança e nos policiais, muitas vezes enquadrados na mesma imagem; nas do enterro ele mira na família e em suas demonstrações de dor e amor. Gracilene, mãe de Matheus, o pastor e as flores são registrados na maior parte delas. Nas imagens do protesto, por sua vez, são os jovens os protagonistas, segurando cartazes com frases de efeito. Dentre as imagens, vemos uma onde um rapaz segura um cartaz com a palavra "peace" (paz) de frente para o Caveirão, o veículo blindado da PM utilizado para incursões nas favelas. Sua postura é desafiadora. Das vinte fotografias divulgadas, algumas imagens se repetem: quatro mostram o sofrimento de Gracilene, três enquadram policiais com fuzis nas mãos e o corpo da criança.

$\mathrm{Na}$ fotografia 01, vemos a perna de Matheus, que aparece sentado na entrada da sua casa. O corpo é iluminado pelo sol que realça o vermelho do sangue que escorre pela porta. Não vemos seu rosto baleado, mas pelo tamanho da perna fica claro que se trata de uma criança. Do lado esquerdo, todo de preto e com um fuzil na mão, a mesma arma usada para matar o menino, vemos um policial. Ele está de pé, de frente para o corpo, em uma postura que parece observar a cena. A composição une algoz e vítima em um mesmo quadro. Nosso ponto de vista está ao lado da figura do assassino.

Com o texto que circulou, aprendemos que Matheus, com metade do corpo pra fora, metade para dentro de casa, saía para comprar pão quando recebeu um tiro disparado por um

11 O "auto de resistência" foi uma medida administrativa criada durante o regime militar no país, que tem sido utilizada desde então para evitar a prisão em flagrante do agente envolvido em homicídio durante uma ação policial. O estado do Rio de Janeiro possui o maior índice de assassinato por "auto de resistência" do país. 
dos quatro policiais que estavam à procura de traficantes de drogas. Ele morreu na hora. Não corria pelas ruelas, não estava no meio do caminho, não podia ser confundido com um traficante. Sua pouca idade impediria os policiais de enquadrá-lo como criminoso, vítima de um auto de resistência. O lugar onde ele se encontrava também. Mostrar que tratava-se de uma criança inocente, como fez Naldinho, serviria para garantir a idoneidade e a dignidade de Matheus, assim como de sua família.

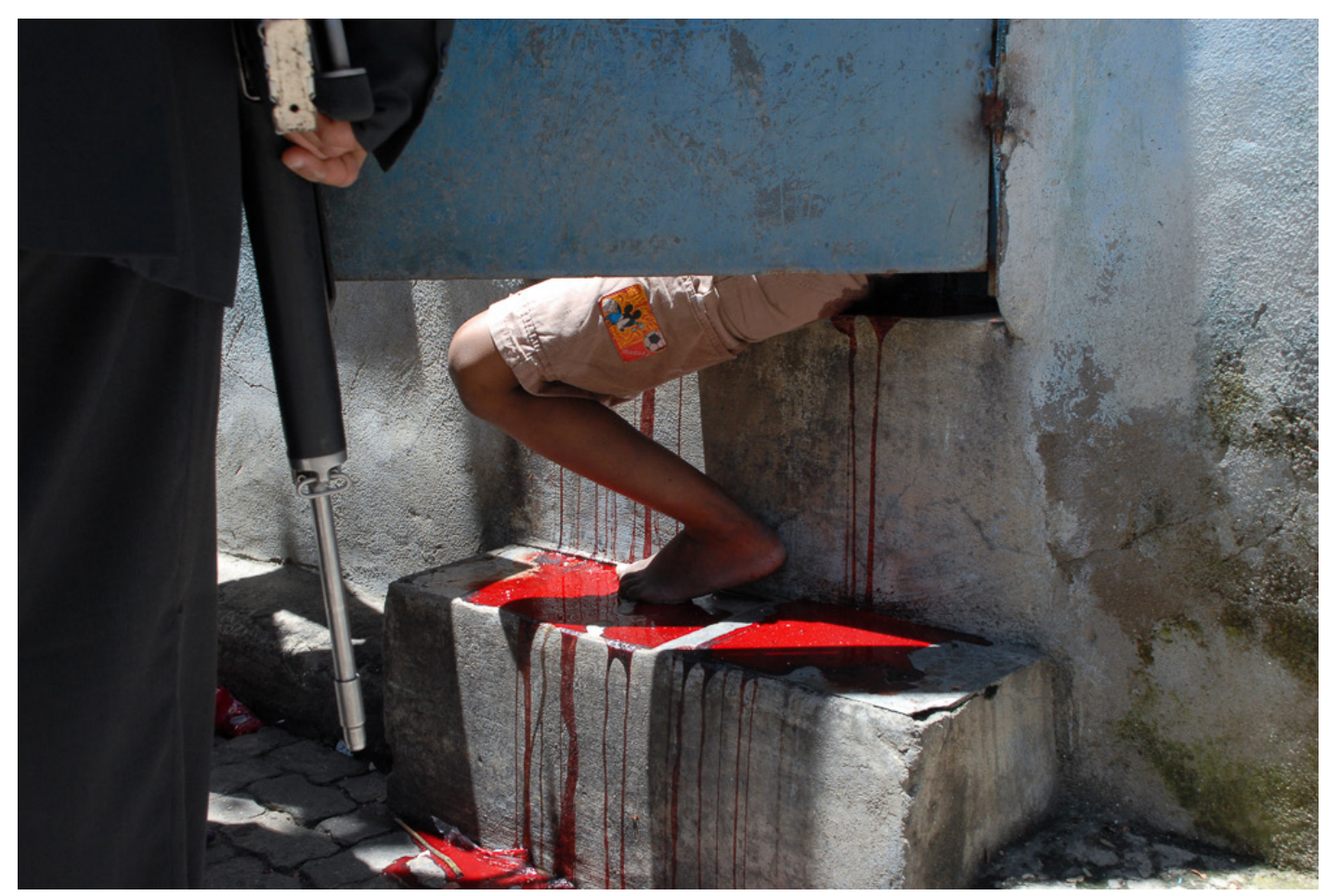

Fotografia 01

O fotógrafo contou que produziu essa imagem com o objetivo de mostrar, em um mesmo enquadramento, a tragédia e a causa dela: esta seria uma imagem forte o suficiente para demonstrar a violência sofrida. "Eu queria fotografar o contexto [e não os cadáveres]", ele disse. Mas foi através da foto a seguir que seu protesto ganhou força. Após ter fotografado o corpo da criança à distância, por causa da grande aglomeração de pessoas que estavam em volta da cena, e a partir do convite da perícia, Naldinho começou a fotografá-lo mais de perto. Foi quando o retiraram da porta de sua casa e o esticaram no chão. O jovem fez novas fotos para a perícia que, em seguida, cobriu a criança com um lençol, deixando sua mão de fora. Ao ver a pequena mão aberta, com uma moeda de um real no meio, suja de sangue, pensou: "é esta a foto". A “imagem da moeda", como ficou conhecida a imagem da mão de Matheus semiaberta, tornou-se um símbolo da luta contra a violência policial nas favelas cariocas e garantiu a "veracidade" da história. O menino não segurava uma arma ou um pacote de drogas, mas a unidade do dinheiro brasileiro, que seria usado para comprar pão, cena comum da vida familiar brasileira. $O$ pouco valor da moeda, assim como a simbologia católica ligada ao pão potencializaram a imagem da mão manchada de sangue que, por si só, já era bastante forte. Ela reunia tantas informações importantes que o fotojornalista Domingos Peixoto sugeriu que Naldinho a enviasse para um concurso de fotografia, estando certo de que ele levaria o prêmio. Mas ele se sentiu incomodado com a ideia: 
Eu ia inscrever a imagem, mas aí pensei: poxa, ganhar dinheiro com essa porra? Imagina, a morte do meu sobrinho... aí vem um cara ganhar dinheiro com uma foto? Eu não acho justo não. Se eu não quero pra mim, eu não vou querer pros outros, sabe? Quando ele falou isso eu até fiquei... Eu pensei, pensei... Se eu ganho, talvez eu poderia ajudar a família também...

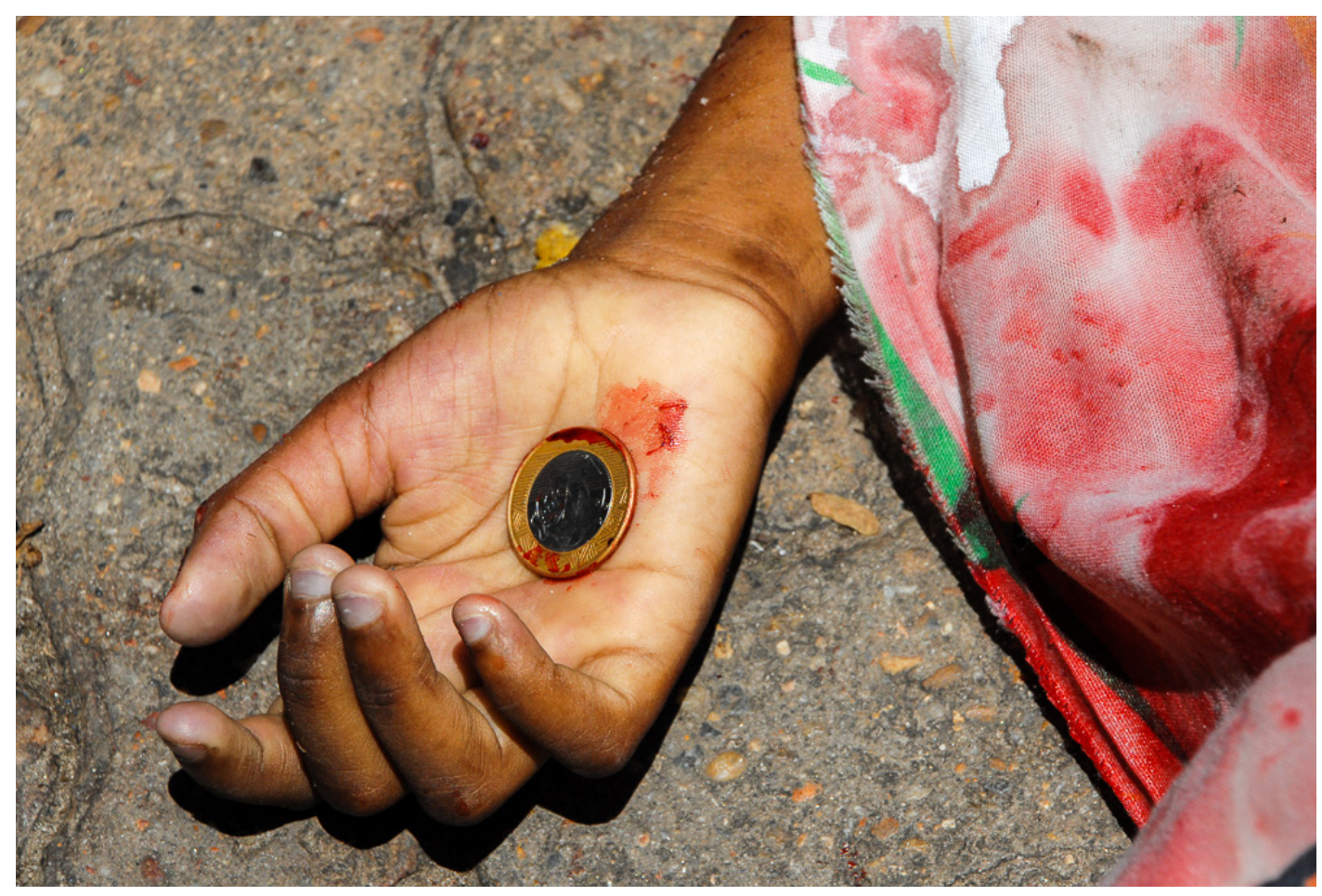

Fotografia 02

A proximidade com a realidade fotografada, que o fazia imaginar que a situação poderia ter acontecido com alguém da sua família, fez o fotógrafo se colocar no lugar dos familiares da criança e se sentir desconfortável com a possibilidade de premiação do registro do cadáver. Ainda que tenha comercializado a imagens em diferentes meios, e que tenha ganhado dinheiro a partir da venda dela (sempre, segundo ele, doando-o de forma anônima à família da vítima), receber um prêmio trazia implicações morais com as quais o fotógrafo não se sentia à vontade. Outro fator de transtorno para ele era a associação da imagem à sua pessoa. Ainda que sentisse orgulho de ter conseguido concretizar em uma imagem parte de suas inquietações políticas, Naldinho se sentia mal pelo tema fotografado. Apesar dos sentimentos contraditórios em relação à fotografia, contudo, ela foi extensamente publicada em jornais, revistas, mídias alternativas, relatórios de ONGs etc., tanto dentro quanto fora do país, mesmo anos depois da morte da criança. Tornando-se a mais vendida da história do Imagens do Povo.

Para contar a história de Matheus, entretanto, ele considerou importante registrar seu enterro e os protestos dos amigos, familiares e moradores locais. Sua vontade era de, através da dor, mostrar a força dessas pessoas, que elas eram lutadoras. A fotografia 03, registrada no velório, mostra em close Matheus e sua mãe. A imagem registrada de perto exibe o sofrimento da mulher que, inconformada com a partida prematura do filho, grita sua perda. Sua mão está sobre a cabeça do menino, que cabe dentro dela. Uma mão masculina parece se aproximar para consolá-la. Todos são negros. Suas peles contrastam com o tecido branco sobre a criança. 


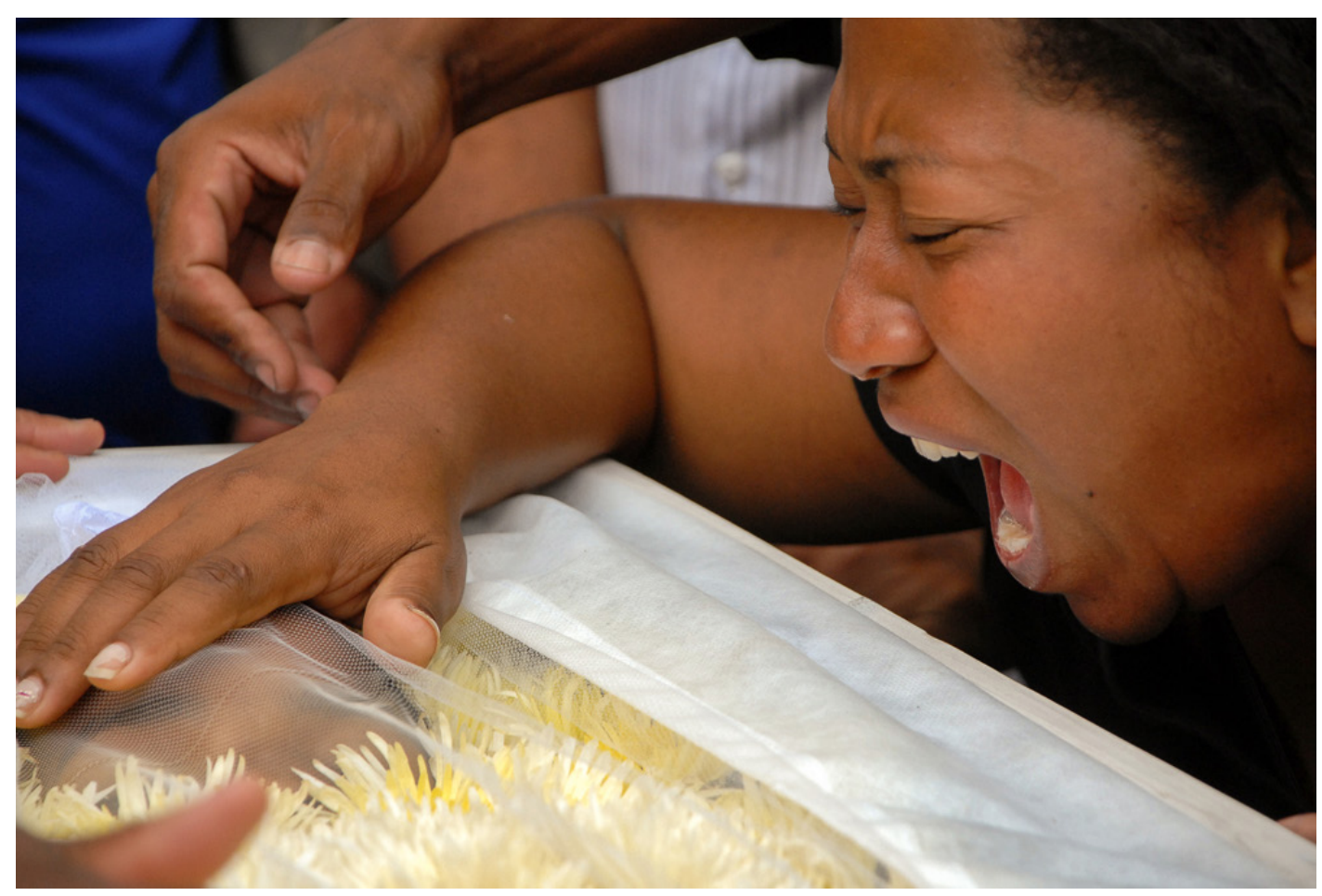

Fotografia 03

A fotografia 04, do protesto organizado durante o enterro, apresenta algumas das muitas faixas levantadas pelos ativistas de organizações que lutam pela preservação dos direitos humanos da população mais pobre do Rio de Janeiro presentes. Nelas, lemos: "Não matem as nossas crianças", "Paz sem voz não é paz é medo", "Maré contra o extermínio", ${ }^{12}$ "Eu só quero é ser feliz, andar tranquilamente na favela onde eu nasci" e "Toda criança tem direito à vida, à saúde e à educação", uma referência ao estatuto da criança, completada com uma referência ao Matheus: "Ele ia comprar pão". As faixas aparecem em volta da multidão que acompanhou o enterro. O caixão está no meio, sendo abençoado pelo pastor. No fundo, vemos os túmulos. Há um fotógrafo em cima de um deles.

O conjunto de imagens - assassinato, velório, enterro e protestos - criou uma narrativa capaz de humanizar a criança, seus familiares e seus vizinhos. E após sua divulgação, o fotógrafo passou a ser procurado para falar sobre o que tinha acontecido, tanto para representantes da mídia quanto da sociedade civil. Revoltado com o ocorrido e excitado com a possibilidade de fazer algo em prol das vítimas de violência policial através de suas documentações, ele decidiu fotografar outros casos com o objetivo de fornecer suas versões dessas histórias para a sociedade.

A partir disso, eu pensei que eu tinha que documentar isso. Fazer um trabalho documental sobre a questão da violência. De toda a violência policial contra as favelas. Eu tinha feito algumas imagens de passeatas de ONGs contra a polícia... Por indignação a partir daquela situação. Aí já me perguntaram isso: por que só a polícia? E o bandido, não tem violência? Tem, mas aí tá nítido, né, cara? Os caras são fora-da-lei. A polícia é pra proteger! É outra parada, é outra relação. Não tem sentido ela fazer isso. Como é que eu vou fotografar um bandido que eu sei que o cara tá fazendo mal? O cara que é policial, ele tá ali para proteger a gente. Se o cara não tá fazendo isso, então eu acho que alguma coisa tem que ser feita. $\mathrm{Na}$ minha cabeça, estava assim. Aí eu comecei a documentar algumas coisas... Acontecia alguma merda com algum favelado, eu ia atrás. Só que a estrutura financeira era foda, né? Você ficar andando de um lado pro outro... Eu acho que eu vou focar

12 Ativistas contra a violência policial nas favelas compreendem tais assassinatos como uma política que visa exterminar a população mais pobre e de maioria negra. 
na Maré. Eu cheguei a ir em outras favelas, mas eu chegava lá sempre depois, né? Eu ia quando eu tinha dinheiro.

Ele estava inconformado com a violência vivenciada, mas satisfeito com a maneira como poderia contribuir, através das imagens, para sua denúncia. Seu desejo, contudo, não durou mais que alguns meses. Foi durante a documentação de outra história, o caso do assassinato de Felipe dos Santos Correa de Lima, um jovem de 17 anos morto por outro policial, que o fotógrafo compreendeu seus limites. Segundo moradores, Felipe foi morto por um tiro disparado por um dos cinco policiais que costumavam se deslocar pela Maré dentro de um automóvel Chevrolet Blazer branco matando pessoas. ${ }^{13} \mathrm{O}$ carro era conhecido e os moradores viviam apavorados. Para justificar o assassinato, os policiais o acusaram de envolvimento com o crime e disseram que ele foi morto em um confronto com traficantes de drogas, em um "auto de resistência".

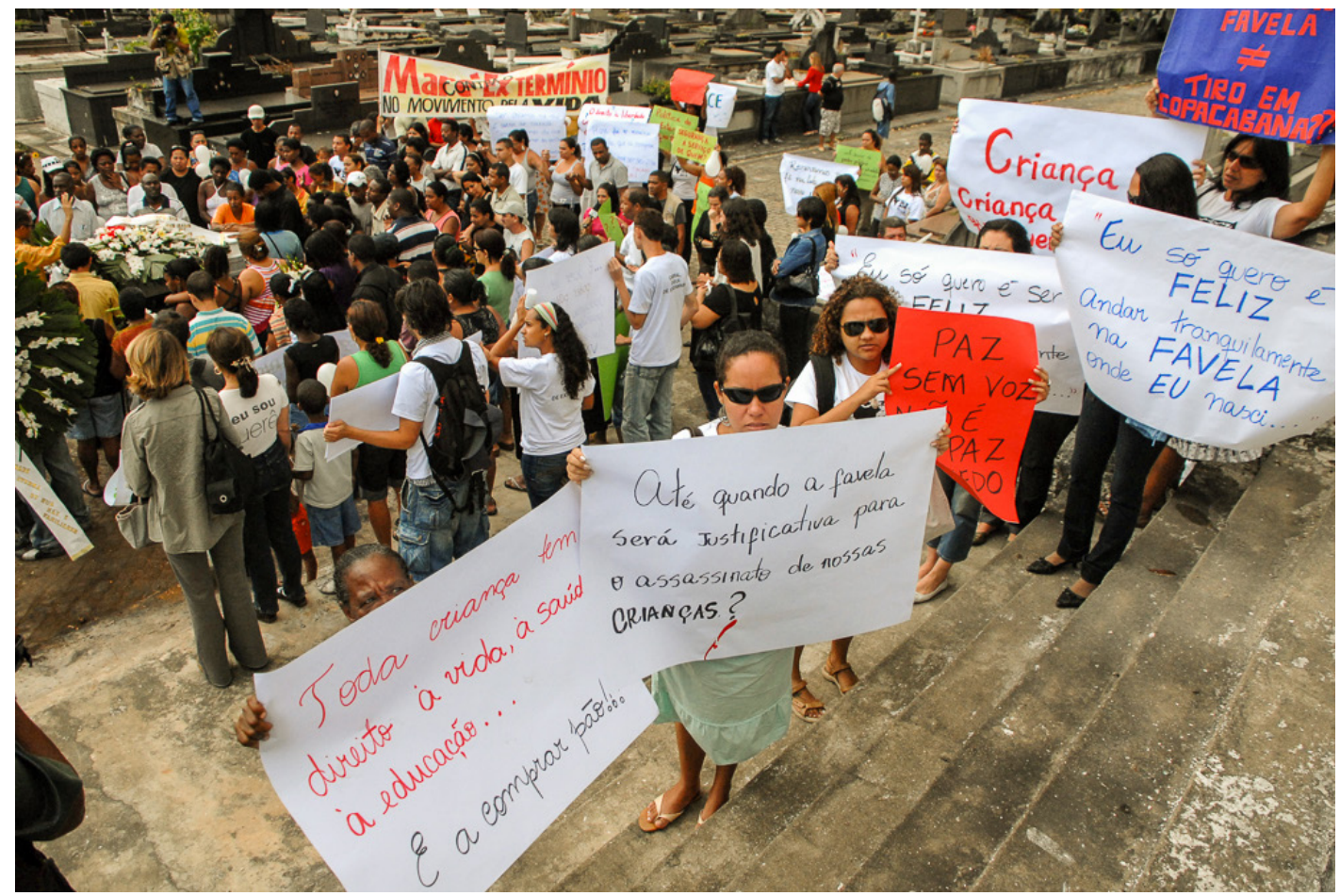

Fotografia 04

Revoltados com o assassinato, agravado pela acusação de envolvimento com a criminalidade, amigos e familiares da vítima decidiram protestar. Depois do enterro, fecharam uma das importantes avenidas da cidade no horário de maior concentração de trânsito. Naldinho os acompanhou junto com outros fotojornalistas durante toda a manifestação, que foi fortemente reprimida pela polícia. Em determinado momento, ao vê-lo fotografando, um policial o acusou de liderar o protesto e o ameaçou de prisão. Ele explicou assim o ocorrido, quando o questionei sobre quando decidiu parar de fotografar a violência policial:

Ah, foi depois que eu quase fui preso, na manifestação que teve seguida da morte do Felipe. 17h, horário de pico, o pessoal estava fechando uma via da Av. Brasil.... Ia dar merda, eu pensei. E vim os acompanhando, da Vila do João até o Bob’s perto da passarela 9. E aí foi quando a polícia veio, e começou o gás de pimenta, isso e aquilo. E aí veio o comandante, veio na intimidação mesmo [...] Aí o policial chegou e ficou me segurando,

13 Ver a matéria publicada por Gizele Martins, Renata Souza e Douglas Baptista com as fotografias de Naldinho sobre o caso no Fazendo Media (fazendomedia.org/2009/diaadia0427.htm). 
e disse: "Eu prendi ele”. Eu disse: "Preso? Mas vai me prender? Como assim?”. Ele disse: "Preso, você estava ajudando...”. Eu falei: "Você tem prova disso?”. Aí ele começou a falar alto, aí eu não tinha como... Vários policiais se juntando, junto com o comandante. Dizendo: tá preso, tá preso. O maluco me segurou e ficou. Aí a coisa foi se agravando, bomba de pimenta pra um lado... [...] Aí a coisa tava rolando, o cara me soltou, eu corri. Saí, fui embora. Não vieram atrás de mim porque a coisa estava acontecendo lá. Fui eu e a Gizele. Gizele chorando horrores, com um medo danado do que estava acontecendo, pra não morrer mais ninguém. Chorando, chorando, chorando...

Acusados de organizar a população para a manifestação, Naldinho e Gizele ficaram apavorados. ${ }^{14}$ Tentaram persuadi-lo, mas não obtiveram sucesso. Precisaram aproveitar um momento de descuido do policial para fugirem. Após o ocorrido, todavia, sentiram medo. Naldinho sabia que a vida de um "fotógrafo popular" é bem mais vulnerável que a de fotojornalistas que trabalham para os grandes meios de comunicação. Decidiu, então, conversar com pessoas mais experientes para avaliar qual seria a melhor atitude a tomar a seguir. Conversou com fotógrafos, jornalistas e um amigo que trabalha na polícia. Este último chamou sua atenção para os grampos que a polícia estava realizando de forma ilegal, especialmente no telefone de ativistas que denunciavam a violência cometida pela instituição. ${ }^{15} \mathrm{E}$ recomendou que o fotógrafo ficasse atento.

Outra grande polêmica, também ligada ao caso do Felipe e a todo o estresse instaurado com as ameaças que começavam a surgir, estava relacionada a um texto publicado no blog policial do jornal O Globo, Repórter de Crime, quatro dias depois do assassinato do jovem, em 17 de abril de 2009. O texto, uma adaptação do original publicado por Gizele Martins, Renata Souza e Douglas Baptista no site Fazendo Media, contava com as fotos do jovem fotógrafo e foi enviado para o jornal pela ONG Justiça Global, que buscava visibilidade para o ocorrido. Ao tomar conhecimento do texto, que fornecia informações sobre o acontecimento, mas também sobre ele próprio, contando que se sentia ameaçado e com medo, Naldinho ficou enfurecido, ligou para a ONG e exigiu a retirada das informações da Internet, ameaçando processá-los. Ao questioná-lo sobre o que o teria deixado tão irritado, respondeu:

O texto! Falou que eu estava com medo, onde eu morava, o que é que eu era... O texto era da Gizele e do Douglas. Aí alteraram... A Justiça Global alterou a porra do texto e enviou pra esse cara aí. Ou ele que fez a partir do texto desses caras aí... Eu falei pra tirar. Eu falei: se deixar essa porra aí eu vou processar vocês. Como é que vocês fazem uma parada dessas? O texto estava muito... Eu fiquei puto da vida. Eu xinguei pra caramba os caras. Chamei eles de filhos da puta. [Com quem você ficou puto?] Com a Justiça Global, porque foram eles que passaram isso pro cara. Disse: "Eu não mandei passar porra nenhuma!" [Você estava com medo do quê?] De que? Eu moro em favela, pô! [Me explica...] Eu estava com medo da polícia vir! O cara falou: morador da Maré, da Baixa do Sapateiro. Já deu o endereço! [Mas por que você acha que a polícia viria?] Se tivesse alguma coisa, que não teve, de incriminar... [O policial que matou o Felipe?] Não o policial, mas alguma coisa contra a polícia, os caras iam vir, pô! Ou não viriam, não sei. Vão dar um fim nisso. [Aí você parou de fotografar casos de violência?] Aí eu dei um tempo. [...] Aí passei a documentar as ocupações das UPPs, indo com a polícia. [Indo com a polícia?] É, pra poder... Quando eles estavam ocupando com as UPPs o Bope subia primeiro. Aí eu ia atrás. Junto com os jornalistas, com os fotógrafos. [...] Mas é a única forma, não adianta. Por diversas vezes eu tentei entrar, mas não conseguia informações.

Com medo das consequências que poderia sofrer (e que já tinha sofrido) ao tentar trilhar seu caminho sozinho, após as ameaças e intimidações, Naldinho decidiu juntar-se a seus colegas de profissão e passou documentar casos de violência adentrando as favelas da maneira

14 Gizele Martins elaborou sua própria análise do caso, em seu trabalho de conclusão no curso de Comunicação Social (Martins 2011).

$15 \mathrm{Na}$ época integrantes de diversos movimentos sociais, especialmente os que lutavam contra a violência policial, estavam recebendo ligações com ameaças e foram informados que seus telefones estavam "grampeados" (com escutas telefônicas) pela polícia. 
anteriormente mais criticada por ele e seus colegas do Imagens do Povo: ao lado da polícia. Era a maneira mais segura para si.

Em 2009, a documentação e a denúncia da violência policial por parte desses jovens fotógrafos era um assunto que preocupava especialmente os coordenadores do Imagens do Povo, Kita Pedroza e João Roberto Ripper. Sem poder garantir a segurança dos jovens frente às ameaças que recebiam, conversavam individualmente com alguns, notadamente Naldinho, e realizavam reuniões coletivas a fim de refletir sobre qual seria a melhor maneira de procederem. No dia 19 de julho deste ano, meses depois do assassinato do Matheus (em dezembro de 2008) e do Felipe (em abril de 2009), houve uma dessas reuniões no Observatório de Favelas.

A reunião foi bastante calorosa e a sala estava cheia. Muitos fotógrafos da agência estavam presentes, especialmente os que fizeram parte da turma de 2004. Como acontecia frequentemente, todos participaram bastante. Cada um quis contribuir com os diferentes pontos da pauta: conquistas e dificuldades da agência, procedimentos para cadastramento dos fotógrafos no Banco de Imagens, direito autoral e patrimonial, carteira de identificação, cobertura de conflitos, crédito do fotógrafo/da agência, pautas que faltam no banco.

Vários fotógrafos relataram dificuldades enfrentadas com policiais ao documentarem irregularidades cometidas por eles. Naldinho continuava revoltado com o que aconteceu com suas fotos, mas decidido a continuar registrando a violência política nas favelas. Kita e Ripper mediavam a conversa, esclarecendo que não pretendiam impedi-los de documentar situações de conflitos, mas que a agência não os pautaria para tais temas. Não era a proposta da agência e não teriam como garantir sua segurança. Ressaltaram que a decisão de realizar tais documentações seria de cada fotógrafo, mas que ela deveria ser feita de maneira consciente. Precisavam refletir sobre como e o porquê de realizar tais imagens e que desdobramentos poderiam ter tais histórias. Era preciso apurar todos os lados das informações e oferecer narrativas que fossem além do registro da morte. Era preciso trazer a história de vida dos mortos, conversar com seus familiares, amigos, professores.

A discussão estava claramente ligada à maneira impulsiva e comovida como Naldinho tinha realizado as imagens dos assassinatos de Matheus e Felipe. Os debates que seguiram na discussão foram interessantes por diversas razões. Por um lado, havia o desejo dos coordenadores de fazer a agência funcionar, colocando questões de ordem prática. Por outro, havia várias demandas (e recusas) por parte dos fotógrafos, como a vontade de documentar conflitos e a hesitação em participar de questões administrativas da agência, que levavam a reunião para diferentes direções.

Depois de discutirem as fotos do Naldinho, Davi Marcos, outro fotógrafo, também relatou um problema com a polícia. Contou que certa vez, ao tentar fotografar policiais recebendo dinheiro perto de uma passarela na qual estava, foi descoberto. Teve medo. Se corresse tomaria um tiro pelas costas, se ficasse levaria uma surra. Resolveu descer da passarela em direção a um ponto de transporte coletivo, andando rapidamente para, ao chegar lá, chamar a atenção das pessoas e se proteger. Funcionou. Os policiais se aproximaram e o questionaram sobre o que ele estava fazendo, mas Davi conseguiu despistá-los ensinando-os sobre fotografia e as funções do equipamento. Contou que dias depois foi parado em uma blitz policial no mesmo lugar, e que os policiais o reconheceram, chamando-o de "o fotógrafo" e o deixando passar. Mas ficou receoso nesta situação de que o moto-taxista com quem estava pensasse que ele era fotógrafo ou 
amigo da polícia, e o denunciasse na favela. Decidiu então explicar toda a história ao motorista, e partiu tranquilo.

Bira Carvalho, também fotógrafo, entrou na discussão para defender que a relação com os moradores da localidade seria o que garantiria a segurança dos fotógrafos populares. O fato de que as pessoas da sua "comunidade" o reconhecessem e conhecessem seu trabalho era o que permitiria que eles circulassem em diversos territórios da Maré, cruzando diferentes facções criminosas, sendo respeitados por todos. Mas se muitos fotógrafos tinham experiência com ameaças e intimidações por parte da polícia, especialmente quando tentavam registrar alguma atividade ilícita que praticavam, poucos tiveram a coragem de divulgá-las em grande escala. As imagens de Matheus, sobretudo, mas também as de Felipe, tornaram-se marcos para o fotógrafo e para o grupo. Mas tais documentações não voltaram a ser realizadas por ninguém do Imagens do Povo. Vejamos o porquê.

\section{SilÊNCIOS, DENÚNCIAS, AMEAÇAS E NEGOCIAÇõES: AS IMPLICAÇÕES dA DOCUMENTAÇÃo dA VIOLÊNCIA COTIDIANA EM FAVELAS CARIOCAS}

Insatisfeitos com a forma como as favelas e seus moradores são comumente representados - como locus de pobreza e criminalidade - os fotógrafos populares dedicam seus trabalhos a mostrar aspectos positivos, que valorizem a população que vive em tais áreas. Tendo que conviver diariamente com os efeitos da proximidade com o tráfico de drogas, não se interessam em documentar o tema, pois acreditam que a grande mídia já o faz demasiadamente. Também defendem que há temas mais importantes de serem abordados, mesmo no que diz respeito a conflitos, como é o caso da violência praticada pela polícia, braço do Estado que deveria proteger (e não executar) a população. A violência policial, política, é mais incômoda pois é, ao mesmo tempo, "oficial" e "criminosa" (Farias 2014).

O risco de sofrer atos violentos de represália e a impossibilidade de fazer circular livremente as imagens, contudo, faz com que a maioria desses fotógrafos não registre tais conflitos. $\mathrm{E}$ foi o que afastou Naldinho dos registros. De acordo com Soares (1993), a censura durante períodos de ditadura ou de guerra civil compromete a circulação de informações sobre a violência política. Intimidações e ameaças - especialmente por agentes do Estado que atuam de maneiras ilícitas - "aceitas" em períodos de "democracia", apresentam importantes funções políticas, como vimos através do trabalho de Naldinho. Ao optar por fotografar cenas de violência explícita experimentadas em favelas, e não a beleza dessas localidades, o fotógrafo tensionou as reflexões sobre as representações dessas áreas por seus moradores. Por tratar de temas até então evitados pelo Imagens do Povo, a documentação do assassinato do Matheus tornou-se um evento crítico, um marco para o grupo como um todo, redefinindo os limites das suas documentação e a forma como gostariam (ou mesmo poderiam) elaborar denúncias sobre a violência experimentada nessas áreas.

Durante a elaboração dos trabalhos, e também após a publicação de suas fotos, Naldinho sofreu intimidações e ameaças, tanto de traficantes quanto do Estado. Nenhum dos lados queria que ele produzisse tais imagens. Ao se colocar como alguém que "esteve lá" e utilizar meios de comunicação visual como suporte para suas ações políticas, ele desafiou representações mainstream de sua realidade. Seu ensaio não apenas trouxe para o centro da cena disputas em torno da 
identificação, elaboração e negociação de conflitos, abordando as múltiplas e complexas construções sociais e intelectuais feitas a partir de uma mesma "realidade", como também enfatizou a resposta elaborada pelos envolvidos nestes conflitos. Ele mostrou sua versão de uma realidade frequentemente vinculada (ou silenciada) por outros. Uma perspectiva até aquele momento inovadora.

Denunciar este tipo de violência, em suas diferentes formas, no calor dos acontecimentos, especialmente baseando-se em imagens, tem implicações de diferentes níveis. $\mathrm{O}$ caráter de prova da fotografia que nos faz acreditar que o que foi registrado em um determinado tempo e espaço aconteceu tal como vemos na imagem, causa curiosidade e medo simultaneamente (Sontag 2003). Os fotógrafos, com suas armas, as câmeras, são ameaçadores. Ao mesmo tempo, documentar a violência sofrida por grupos sensíveis em tempos de instabilidade, "de dentro", é delicado por colocar as vidas dos próprios fotógrafos em risco. Pois se a proximidade carrega uma aura de autenticidade, ela também aponta, especialmente para grupos subalternos, que eles próprios podem sofrer retaliação.

Os fotógrafos do Imagens do Povo desenvolvem seus projetos para mostrar a luta e a dignidade da população favelada. Mesmo quando registram situações de violência, como vimos, o objetivo é humanizar essas pessoas e provar que não são criminosas. As histórias de cada assassinato, mas também das pessoas mortas, são narradas com o intuito de chamar a atenção para o sofrimento que vivem. Pois é o contexto que explica as causas da violência, mesmo quando a violência parece não poder ser explicável.

As imagens de Naldinho circularam de diferentes maneiras, mas prioritariamente como dádivas (Mauss 1974). Seu valor encontrava-se na circulação e no seu poder de afetar as pessoas. As fotografias não eram, para o grupo, mercadorias (ainda que fossem comercializadas), mas expressões de formas de vida, de subjetividades. Além disso, como apontou Patrícia Lanes (2015: 12): "O evento acontecido na Maré em 2008 pode ajudar a entender processos que envolvem o uso de imagens fotográficas (e mais recentemente vídeo) na construção de versões que desautorizam as versões oficiais (legitimadas pelos agentes do Estado, no caso, a polícia)”.

Tal fenômeno ganhou recentemente proporções ainda maiores com a popularização de smartphones, combinados com a possibilidade de publicar imagens instantaneamente em aplicativos como o Nós por Nós ${ }^{16}$, o Instagram e o Facebook. Tais redes sociais transformaram e intensificaram o acesso a diferentes versões das histórias oficiais sobre violências políticas praticadas em favelas cariocas. Mas se ao denunciarem as violências vividas os moradores de favelas buscam fazer uma "limpeza simbólica" (Machado da Silva 2008), raramente tais esforços têm resultado em diminuição da violência. As censuras, ameaças e interditos são atualizados e experimentados por outros meios. Através de repreensões formais, mas também do amedrontamento, de perseguições e de outras violências, simbólicas e psicológicas, ativistas passam a se questionar, eles mesmos, sobre as possibilidades e os sentidos de realizarem determinadas denúncias. Como demonstrei neste artigo, muitas vezes as atualizações das formas como as repressões são praticadas provocam novas formas de violência, e não a proteção contra elas.

16 Nós por Nós é um aplicativo criado em 2016 pelo Fórum de Juventudes do Rio de Janeiro. A ferramenta foi projetada por moradores de favelas com o objetivo de denunciar abusos policiais em tempo real e de forma anônima. 


\section{Bibliografia}

Abu-Lughod, Lila e Catherine A. Lutz (Org.). 1990. Language and the politics of emotion. Cambridge: University Press.

Caldeira, Teresa. 1993. "Comentários a partir do artigo 'A violência política na América

Latina”. Revista Brasileira de Ciências Sociais 8 (21): 44-47. Disponível em <http://www.anpocs. org.br/portal/publicacoes/rbcs_00_21/rbcs21_04.htm>.

Carminati, Thiago. 2008. Imagens da favela, imagens pela favela: Representaçóes de si e do outro nas imagens do povo. Dissertação de Mestrado (Mestrado em Sociologia e Antropologia). Universidade Federal do Rio de Janeiro.

Das, Veena. 1995. Critical Events: An Anthropological Perspective on Contemporary India. New Delhi: Oxford University Press.

Farias, Juliana. 2014. Governo de Mortes Uma etnografia da gestão de populações de favelas no Rio de Janeiro. Tese de Doutorado. Programa de Pós-graduação em Sociologia e Antropologia - IFCS/UFRJ.

Gama, Fabiene. 2012. Fotodocumentação e participação politica: um estudo comparativo entre o Brasil e o Bangladesh. Tese de doutorado. Programa de Pós-Graduação em Antropologia Social e École de Hautes Étudies en Sciences Sociales. Rio de Janeiro: Universidade Federal do Rio de Janeiro.

2009. "Etnografias, auto-representações, discursos e imagens: somando representações”. Pp. 91-114 em Devires Imagéticos: Representações/Apresentações de Si e do Outro, editado por Marco Antônio Gonçalves e Scott Head. Rio de Janeiro: 7letras, Pp: 91-114. 2006. A auto-representação fotográfica em favelas: Olhares do Morro. Dissertação de Mestrado (Mestrado em Ciências Sociais). Universidade do Estado do Rio de Janeiro.

Jasper, James. 1998. "The Emotions of Protest: Affective and Reactive Emotions In and Around Social Movements". Sociological Forum, Vol. 13(3): 397-424.

Lanes, Patrícia. 2015. "Ele só tinha 10 anos": morte, limpeza moral e mobilização virtual em uma favela carioca”. Paper apresentado na XIV Reunião de Antropólogos do Norte e Nordeste. Maceió.

Machado da Silva, Luiz Antonio (Org.). 2008. Vida sob cerco: violência e rotinas nas favelas do Rio de Janeiro. Rio de Janeiro: Nova Fronteira.

Martins, Gizele. 2011. Cidadãos e vítimas: a representação de dois crimes nos jornais cariocas. Rio de Janeiro: Pontifícia Universidade Católica do Rio de Janeiro. Departamento de Comunicação Social. Graduação em Jornalismo. Monografia de Bacharelado.

Mauss, Marcel. 1974. "Ensaio sobre a dádiva. Forma e razão da troca nas sociedades arcaicas". Sociologia e Antropologia. v. II. São Paulo: Edusp.

Prelorán, Jorge. 1987. “Conceptos éticos e estéticos en cine etnográfico.” Pp. 73-119 em El cine documental etnobiográfico de Jorge Prelorán, editado por V. ROSSI. Buenos Aires: Busqueda,.

Soares, Glaucio. 1993. "A violência na América Latina". Revista Brasileira de Ciências Sociais 8 (21): 22-39. Disponível em

<http://www.anpocs.org.br/portal/publicacoes/rbcs_00_21/rbcs21_02.htm> .

Sontag, Susan. 2003. Diante da Dor dos Outros. São Paulo. Companhia das Letras.

Valdean, Francisco. 2013. Maré em Imagens: preto e branco e a cores. Imagens e representações. Trabalho de Conclusão de Curso (Graduação em Ciências Sociais). Universidade do Estado do Rio de Janeiro.

Vianna, Adriana e Juliana Farias. 2011 "A guerra das mães: dor e política em situações de violência institucional”. Cadernos Pagu 37 (julho-dezembro): 79-116. 


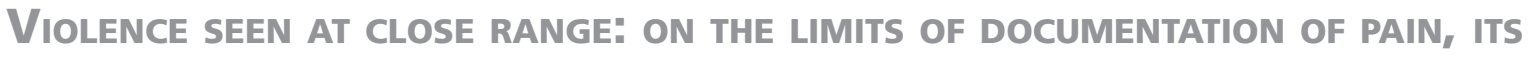 DENUNCIATION AND THE DEMAND FOR JUSTICE}

This article discusses a photographic documentation of the corpse of a child murdered by police officers in a favela in Rio de Janeiro, and the events that followed its publication. Produced by a young photographer living in the same favela, Naldinho Lourenço, the documentation of the murder and the reactions to it point to the dynamics and limits of the photographic record of police violence by amateur photographers. Naldinho belongs to the photo agency "Imagem do Povo", which seeks to produce positive images of marginalized people in order to the combat the stereotypes they face. Naldinho's work was an exception to the agency's production, and provoked threats against him, making the agency ponder on the possibilities, the needs, and the consequences of such records. Combining quotes, images and accounts of events, the author reflects on the photographic self-representation of slum dwellers in Rio.

Keywords: photography, police violence, activism, favelas, Rio de Janeiro

Recebido em: 2016-11-30

Aceitado em: 2017-05-25 